UDC 81'42:004.77

DOI https://doi.org/10.32838/2710-4656/2021.6-2/09

Mehdiyeva M. B.

Azerbaijan State Pedagogical University

\title{
PROFESSOR ZARIFA BUDAGOVA'S SCIENTIFIC CONSIDERATIONS ON THE COMMA
}

Speech culture, orthography, orthoepy, alphabet, translation issues, punctuation are including to the fields of language application. Punctuation is taken as the main theme of different research works. Every intellectual person must know the moment of use and development of punctuation marks. Punctuation is a set of rules for the use of punctuation marks and is particular importance in the regulation of orthography. Sometimes punctuation and punctuation marks are equated. However, Zarifa Budagova correctly distinguishes punctuation from punctuation marks and notes that punctuation is a system of rules for defining their places. As for us, Zarifa Budagova's approach is more correct and exact. Indeed, when rules do not form a system, they become a branch of science which called punctuation. It should also be noted that punctuation can be counted, and punctuation is a general concept. It would be more accurate to say that punctuation marks are the object of study of punctuation. In general, when we look at our linguistics, we see that many methodological tools and scientific books have been written on punctuation. We also find information about punctuation in the syntax section of Azerbaijani language textbooks. Prof. Zarifa Budagova's views are of particular interest in this field. We come across information about punctuation before and after the great scientist. For example, prof. M. Huseynova, H. Aliyev, A. Kazimov, V. Dumanoglu and I. Asgar, N. Palangovand other linguists wrote a book about punctuation marks. The book entitled "System of punctuation in the Azerbaijani language" published by the Academy of Sciences of Azerbaijan is also in the list of recent literature. Linguists have a different point of view. However, Z. Budagova's book entitled "Punctuation marks in the Azerbaijani language" still retains its significance. The scientist's book is always used as a source. It should be noted that among the punctuation marks, a comma is chosen for both the most controversial and the frequency of processing. The most common punctuation error in written speech is almost comma-related. The report also touches on the development of this sign. The rules given by Z. Budagova in connection with the comma are involved in a comparative analysis.

Key words: punctuation, punctuation marks, comma, punctuation problems, intonation.

Formulation of the problem. Comparative analysis of punctuation issues. There are such sections of linguistics that, they are valued as topics of study by various specialists being part of both linguists' and non-linguists' interests. One of these sections is the punctuation section. The punctioans are taken as main theme of various researches. There are also applied sections of linguistics differing from scentific-theorological theme as morphology, syntaxis, lexicology, ethimology and semantics. Not only linguists, but also educators and people working in law, press, culture, politics, economics and other fields work in these sections.Language application areas include speech culture, spelling, orthoepy, punctuation.

Knowing punctuation marks, mastering them well, using punctuation marks in its proper place is one of the most necessary and important factors in the written speech of every citizen and literate person. Every intellectual must know the points of use and development of punctuation marks. Not native language and literature teachers, journalists, press workers, but also all Azerbaijani intellectuals have to pay attention to the protection of writing norms, the issues of speech culture. Sometimes punctuation is identified with the concepts of marking signs.

For example, A. Abdullaev writes: "Besidesthe alphabet, punctuation marks are used in writing. The usage purpose of these signs is to express the oral speech as the same in the writing. To express so that the reader not to bear the difficulty understanding the writer's subject, and can vivify as it was. The system of these signs is called punctuation, or marking signs" [2, p. 407]. But Zarife Budagova differs the punctuatios from marking signs very correctly and notes that,punctuation is the rules system of placing the marking signs.

In my oppinion Zarifa Budagova's approach is very correct. Really, the rules changes into the punctuations science field not separatel, but in system form. Also must be noted that the marking signs can be counted, but punctuation is common perceiption. 
If we say that "The "Marking signs" is applied object of Punctuation" would be more correct. N. Palamgov noted that the word "punctutaion" had been described in 37 dictionaries and more than 15 linguistic literature [118, p. 11]. But according to Kazimov, the section dealt with marking signs is called punctuation in general.

As we know the task on the correct forming of written language mainly falls on marking signs. The marking signs have been auxiliary means incorrect perceiption of the text, and carry significant communicative function.Punctuation is the graphical system of language. Z. Budagova writes:"the marking signs are important graphical means inclearly understanding the thought andin the correct, expressive pronunciation of the writing.If these are not corerectly used, the confusion occurs in thought. The content identity between oral speech and written speaach is violated" [33, p. 3].

If we look through the the marking signs formation hystory, we see that, they had not appeared in the same time with writings, they appeared after letters.

A.Gurbanov writes: "In ancient times, the writings were subscribed wholly adjoined.And it made reading and writing difficult...The demand of the words division in writings appeared an the base of improvements of writing culture,incrising for writings,occuring the writings in different forms and subjects, and besides this the thought can be clearly conveyed to the reader" [85, p. 687]. Scientist notes that: "This showed itself in different ways:some nations put vertical lines between the words, and some used various signs". But Later, the space was put between the words and at last usage of marking signs was began $[85$, p. 688].

It must be noted that the usage of marking signs has begun from phonographic subscribtion. The marking signs were not used in other types of subscribtions. It is known the marking signs were firstly used in Finikia and Greese. The marking signs have benn widely used since XIII century. Since now every languge has created own marking signs accordint their national characters. In XV century, the number of marking signs was increased realted to the book printing appearence. The symbols such as question and exclamation has been used correctly since XVIII century.we meet the special symbol replacing the dot in Azerbaijan writings in "Kitabi-Dada-Gorgud" written in 1073. In Dresden copy the asteric symbol put on the every sentence end could not be spreaded so widely.

M. Jahangirov writes that since the $30 \mathrm{~s}$ of XIX century the acquaintance with the Russian and European writing system, the of new schools establishment, and the development of textbooks have increased the need to use of the marking signs. That's why, the tendency to use marking signs used by western peoples has increased, and some aquired marking signs had been begun to be applied.

For example, in the textbook "Grammar of the Turkish-Tatar language" published by Mirza Kazim bey in 1839, in the eight-page text given to students in the Arabic alphabet for their work, he used only 2 marking signs and every of them in two places,a star-like sign (*) and a hyphen (-) instead of a dot (.) [48, p. 181]. But the author does not consider Mirza Kazim Bey's initiative as the first applied sample of the marking signs in Azerbaijan language right. He brings to the attention that the marking sign issue was firstly scientifically substantiated on a relatively broad sense by M.F. Akhundzadeh, and notes that in the last quarter of the 19th century the marking signs opened the way to the press. The marking signs used in Azerbaijan and Rusiian language are included in even textbooks. Firstly the marking signs were used in "Akinchi" newspaper. Q. Kazimov writes that there are 3 tendencies in the explanation of bases of Punctuation. One of them is meaning, the other one is syntactic formation and the last one is intonation. As to Q. Kazimov the most important among these factor is the meaning issue.Equally to this, the structure and content of the sentence have a definite purpose, and the meaning expression is basic and decisive.

Analysis of recent research and publications. Some of scientistthought really bear great interest. One of these issues is that, the usage of marking signs is not related with the intonation.Somehow we agree with it. Biz do hardasa alimin fikirləri ilo razıyıq. Because giving the inderect speech in parentheses, the relation of the use of indirect speech in parentheses cases with the intonation and the use of question marks in parentheses to convey different feelings to people.

This is because the use of indirect speech in parentheses, the relation between the cases of question marks in brackets in order to convey the various feelings to people and intonation doeas not exist or is very weak.

I. Kazimov notes that "the punctuation marks are not put on the base of this or other principle; it is put on a number of principles unity base - grammatical and semantic, as well as intonation relations" $[25$, p. 9]. But as to the famous Azerbaijan linguist A. Damirchizade, "the usage of punctuation marks is difficult process".

Punctuation marks is a complex process connected with the lexical units inside the sentence, 
between the members of a sentence, the components of a complex sentence, and the meaning, purpose, and psychological case at the end of the sentence [58, p. 167]. But in general looking through at our lingistics we see that,many methodical aid books have written related to punctuation. As well as, we meet information about punctuation marks in the syntax section of Azerbaijani language textbooks. We can add the book "Rules for the development of punctuation marks" by H.Aliyev and A. Kazimov [64], "Punctuation marks in the literary language of Azerbaijan" by V. Dumanoglu and I. Asgar among the recent years written books about punctuation [66]. İn M. Huseynova's book "Punctuation issues in the modern Azerbaijani language" explains the issues related to punctuation marks which the author considers necessary and important in the teaching process in terms of modern achievements of linguistics, also the rules of punctuation marks usage are analized in the base of rich language materials. This book is the edition of the $2017^{\text {th }}$ years. N. Palangov's monograph "Some problems of punctuation of the modern Azerbaijani language" is one of the perfect works written about punctuation marks and rules of their usage [118]. The book "System of punctuation marks in the Azerbaijani language" edition of the Azerbaijan AS is also in the list of recent literature [25]. Zarifa Budagova expressed her scientific opinions related to punctuation marks, in 1965, she published a book "Punctuation marks in the Azerbaijani language" together with R. Rustamov in the publishing house of Azerbaijan AS. The editor of that book was one of the founders of Azerbaijani linguistics, prof Mukhtar Huseynzade. In 1977 Z. Budagova further improved this work in volume and content and delivered it to the scientific community. These two books are considered a monographic rersearch about punctuation marks. A. Akhundov called Z. Budagova's work "Punctuation marks in the Azerbaijani language" the most extensive and comprehensive research on the punctuation marks usage place in our language. Scientist's "The punctuation marks are the key of wwritten speech" article is interesting too.The article deals with usage rules of comma [31, p. 25-31].

M. Shiraliyev notes that "punctuation marks appliance has been possible after Azerbaijan writing passing to new alphabet". But syntactic rules are not always expected in the punctuation marks usage $[129$, p. 8]. But it is special that, this case is noticable in comma usage. Zarifa Budagova's work "Punctuation marks in the Azerbaijani language" will greatly help to journalists, writers and teachers $[129$, p. 8].
Eljan Salmangizi's article "Punctuation marks: where to use?" was published. In the "Kaspi" newspaper, the issue of January 9-11, 2010. The author mentions Zarifa Budagova's name as the author of the latest accepted system of rules for punctuation marks [123].

A. Afendizadeh too, specially notes Zarifa Budagova's services in systematization punctuation rules. He points out that Zarifa Budagova's work "Punctuation marks in the Azerbaijani language" as being used as the main source [60, p. 67].

Zarifa Budagova mentions that, if the punctuation marks are not used in their places then our written speech is deprived of certain amenities. The scientist points out that we go against the rules of grammar when we do not strictly follow the punctuation marks. B.A. Shapiro notes that "punctuation can be apparently the same in different languages, but their meanings and uses are different" $[174$, p. 6].

Zarifa Budagova reports that the following punctuation marks are used in modern Azerbaijani language: dot, comma, semicolon, colon, question, exclamation mark, hyphen, three dots, brackets, quotation marks. We have to Note that a dot, a semicolon, three dots, double-dots, a question and an exclamation mark carry separating feature but inverted comma and bracket distinguishing and a comma and a hyphen carry both distinguishing and separating functions.

The scientist have explained the punctuation marks characters very widely.. Even today the rules he wrote are still very actual to literate writing. It is true in this this book, the usage of punctuation marks in other literatures also mentioned above was touched. But some of the opinions expressed in these sources do not justify themselves in all cases in the modern Azerbaijani language. Because our language is developing and enriching, the current state of the language is not the same as 50-60 years ago. Because of punctuation marks being as a dynamic system, while language develops punctuation is renewed and the means of expression expand. But our comparisons show that in spite of all this, great number of rules in Zarifa Budagova's book "Punctuation in the Azerbaijani language" are still valid today.

The comma mark causing for more disscussion and forusagefrequency is chosenamong thepunctuation marks. The main mistake in punctuation marks is with comma mark. In contrast to dot mark, the comma mark does not have any relation with the sentence border. The comma and the hypen differs from othe punctuation marks The both punctuation marks carry separating and distinguishing characters. The 
scientist conveys to the attention that, comma is put before the conjunctions connecting the components of compound sentences as Nə(də),ya(da), Həm (də) .

The scientist notes that we dont need to put comma mark after using the particle with noun, pronoun, adverb and auxiliary parts of speech. B. Khalilov agreed with this and noted the sample in Z. Budagova's book as same as in his own book. "Snow freezes the person" [75, s. 200].

Z. Budagova emphasizes the putting comma among homogenous members as important condition. As well as, she gently points out that, if the particles are used with the words as "gor, gerek, gorum, qoy, gel, gelsene, bax" they are not homogenous members. That's why comma is not put after them. She gently conveys intersting points in putting or not putting comma after subject. The Scientist emphasize that, no need comma after subject in order the subject being comprenced as adjective of word coming after itself. In this case the meaning of sentence must be paid attention.

Z. Budagova considers acceptable putting comma after noun, number and adjectives proceeding the subject ecpressed with this or that pronoun. If the subject is this as person and that as indicative pronoun proceeding pronoun, verb, adverb and auxiliary parts of speech, we dont need to put comma after them. Of course it is Z. Budagova's opinion. B.Khalilov confirms these considerations too. But as for us, this rule is not always true.

For example, comma must not put in the sentence "He went at night" // "O gecə getdi". But if we dont put comma in this sentence, the meaning of this sentence may be understand as double meaning. If we put comma after "He" (O)it will be subject, if we dont put "He" $(\mathrm{O})$ will be adjective. It means that if pronoun does not determine the word coming after it and this does not create any semantic form of sentence comma does not needed. Above sample comfirms this too.But Q. Kazimov notes comma must be put after personal pronoun (before noun, adjective abd adverb) [82, p. 154]. N. Palangov's opinion about this is also interesting. He writes: "it is clear that comma put after this (bu) and that (o) pronouns has been presented differently in various times, But lately the main demand is this 1) this and that pronoun as subject; 2) after them must be noun, adjective, countand adjective" [118, p. 51-52].

N. Palangov also supports Q. Kazimov's opinions but İ. Kazimov says that the coma must not put if this (bu) and that (o) pronouns as subjects proceeding verb and auxiliary parts of speech [25, p. 29]. V. Dumanov and I. Asgar consider the same rule correct They also note that,the coma is not put if adverb comes after the pronouns "this" and "that" [66, p. 46]. In reality, such opinion variority creates freedom in comma use. It must be condemned that,even now opinion varioity in this theme shows itself it means that there is not exact system. A. Afendizadeh's opinion attracts our attention: "There are also case when no need to put comma after "this and "that pronouns coming in front of nouns. For example." He returned from Kiev", This is Nasimi monument", If the pronouns "this and "that " are subject, then no need to differ them from auxiliary words. Because in this case, those pronouns can not be ever adjectives. For example;" He is a welder too" [60, p. 76]. A. Afendizadeh considers that.it is acceptabel to use comma after this words if auxiliary words proceed the pronoun subjects. The scientist's opinion is also interesting. He writes: "it is not so reasonable when comma differs Those pronoun subjects does not matter what part of speech come after them [24, p. 149].

A. Afendizadeh maintains that punctuation is directly related to syntax and does not consider it acceptable to connect it with morphological categories. In our opinion, it is necessary to create a unit rule for the use of commas after these pronouns in the position of the subject. In this case, freedom is deprived from the use of commas.

M. Shiraliyev and M. Huseynov considered it acceptable to put commas in nouns, adjectives and numbers after these pronouns [127, p. 9]. A. Rahimov speaks about punctuation in the book "Integration and orthograpy rules in the literary language of Azerbaijani Turkish", but he didnot explain to the development of commas after the use of these pronouns [120, p. 183].

I. Mammadli considers it acceptable to put a comma after these pronouns when it comes to the part of the sentence expressed by the remaining parts of speech, except for the verb and auxiliary parts of speech. According to I. Mammadli, "when these pronouns are used in the position of the subject, if they are followed by verbs and auxiliary parts of speech (except for adjectives and modal words), commas are not put" [102, p. 9]. A. Akhundov notes that "most of the books written about punctuation marks reveal the grammatical essence of punctuation marks. Phonetic function is not important. In particular, the comma is loaded with grammatical load from beginning to end. Is that really so? Why, for example, should we put a comma after the word "he was spending his time reading a book" when there is no gap between that word and the word book? Or, why not use the punctuation mark in the sentence "He also loved to read a book" when there is a pause between 
that word and the word itself? But do I see that it is written in linguistics books? [10, p. 185]. A. Akhundov also draws attention todot (.), dot with comma (;), minus (-) sign. The scientist does not consider the use of punctuation marks in the article to be positive, and the limited use of punctuation marks in Russian and European languages is commendable. In our opinion, if punctuation marks are used in our written speech when necessary, their place of use will be precise and indisputable. It should be noted that if the 54 places of the comma are indicated and required in each case, it becomes very difficult to remember these rules and apply them in written speech. For comparison, in English, the leading language, the comma is rarely used, that is, when it needs to be used more.

Z. Budagova says that commas should be used in the same words that are repeated: pleading, asking, cherishing, swearing. He also points out that the word is preceded by a comma, which characterizes the message, completeness and envelope, that is, especially, especially. The book explains in detail the words that need to be separated by commas, speeches and exclamations. The scholar also points out that the commas of the suffixes $-\mathrm{ib}^{4}$ and $-\mathrm{araq}^{2}$ do not have a comma after them when they act as a style, time, reason, purpose envelope in a sentence. I. Kazimov, unlike Z. Budagova, notes that this type of composition is used only in the function of time envelope, followed by a comma [25, p. 32]. However, if these figurative verb conjugations also serve as a news function, they are followed by a comma. Admittedly, the development of commas after these suffixes is currently confusing. It is written in the book "Questions and answers from the Azerbaijani language": "In general, the rules of verb conjugation and comma after verb conjugation have not been specially studied in our linguistics; this issue is still controversial " [63, p. 22]. M. Adilov's opinion is also interesting. He writes: "The point is that the comma is usually associated with a verb conjugation. However, the verb conjugation has nothing to do with the comma. Verb conjugation is a morphological category. The rules of commas and other punctuation marks are related to syntactic events" [4, p. 20].

Conclusion.Our observations give grounds to say that Zarifa Budagova's monograph, which N. Jafarov called "instruction", contains complete and detailed information about punctuation. In the book, the scientist gave a wide, complete and detailed description of the rules of punctuation. We looked at some of them. It is always worthwhile to evaluate this book written by a scientist as a tool that we need. Because in this material the professor managed to create a complete and complete picture of the place and essence of the development of punctuation marks for his period. It is safe to say that this book set a precedent for most linguists. The scientist has proved that punctuation is a type of meaningful sound and is an important means of ensuring the exhaustion of parts of the speech flow.

Scientific novelty. The research paper deals with the issues of punctuation in modern times, especially the use of commas. Comparative research has been conducted on this theme in synchronous and diachronic aspects, which reflects scientific innovation.

\section{References:}

1. Abdullayev, A.Z., Modern Azerbaijani language: [in 4 volumes] / A.Z. Abdullayev, Y.M. Seyidov, A.Q. Hasanov. Baku : East-West, 2007. 424 p.

2. Palangov, N.Q. Some problems of modern Azerbaijani language punctuation. Baku : Science and education, 2019. $124 \mathrm{~s}$.

3. Budaqova, Z.İ. Cases of violation of grammatical norms. Baku : Language culture, 1974. P. 27-30.

4. Qurbanov, A.M. General Linguistics: [in 2 volumes]. Baku : Nurlan, 2004. 748 p.

5. Cahangirov, M.P. Formation of the national literary language of Azerbaijan. Part I. Baku: Elm, 1978. 235 p.

6. System of punctuation marks in the Azerbaijani language / ANAS, Nasimi ad. Linguistics In-tu; scientific ed. M. Naghisoylu, T. Ismayilova. Baku : "Europe" publishing house, 2020. 256 p.

7. Damirchizade, A.M. Modern Azerbaijani language: I part. Baku : Maarif, 1972. 308 p.

8. Aliyev H.Q., Rules of development of punctuation marks / H.G. Aliyev, A.S. Kazimov. Baku : Elm, 2011.71 p.

9. Asgarov, I.V., Dumanoglu, V. Punctuation marks in the modern Azerbaijani literary language. Baku : Science and education, 2016. $179 \mathrm{p}$.

10. Hüseynova, M.N. Modern Azerbaijani language: punctuation issues. Baku, 2017. 244 p.

11. Budaqova, Z.I. Punctuation is the key to written speech. Baku : Language culture, 1972. P. 25-31

12. Shiraliyev, M.Sh. Issues of language culture. Issues of speech culture. Baku: 1969. P. 3-12.

13. Salmangizi, E.S. Punctuation: where to use? URL: http://www/anl.az/down/meqale/kaspi_en/2010/ yanvar/102300.htm.

14. Efendizade, A.R. On the use of commas in two cases. Baku : Issues of speech culture, 1988. P. 66-76/

15. Shapiro, A.B. Modern Russian language. Punctuation. Moscow : Education, 2006. 296 p. 
16. Khalilov, B.A. Modern Azerbaijani language (phonetics, writing, alphabet, graphics, orthography, orthoepy). Baku: Nurlan, 2007. 310 p.

17. Kazimov, Q.S. Modern Azerbaijani language (Morphology). Baku : Science and education, 2010. 398 p.

18. Azerbaijan linguistics: [in 3 volumes] / ANAS, Nasimi. Linguistics In-tu; tart S.H. Mehdiyeva, S.A. Sadigova (ed.), I.M. Tahirov (ed.). Baku : Abis Alarco, 2013. 438 s.

19. Shiraliyev, M.A. Punctuation marks of the Azerbaijani language / M.A. Shiraliyev, M.H. Huseynov. Baku : Azer Publishing House, 1945. 14 p.

20. Rahimov, A.R. Integration and correct writing rules in the Azerbaijani Turkish literary language. Baku, 2008. $215 \mathrm{p}$.

21. Mammadli, I.O. On the points of development of punctuation marks in writing. "Azerbaijan" newspaper, 2014. February 27, p. 9.

22. Akhundov, A.A. About punctuation again. Baku : Language and culture, 1992. Pp. 181-189.

23. Aliyev H.Q. Questions and answers in the Azerbaijani language / H.G. Aliyev, A.S. Kazimov. Baku : ADPU publishing house, 2019. $162 \mathrm{~s}$.

24. Adilov, M. Verb conjugation and comma. "Azerbaijani language and literature teaching" Collection of methodical articles, I edition. Baku, 1961. S. 20.

\section{МехТієва М. Б. НАУКОВІ ІДЕЇ ПРОФЕСОРА ЗАРИФИ БУДАГОВОЇ 3 ПУНКТУАЦІї}

Культура мови, орфографія, орфоепія, алфавіт, питання перекладу, пунктуація входять до сфери застосування мови. Пунктуачія є у філології провідною темою багатьох досліджень. Кожна грамотна людина має знати основи використання та застосування розділових знаків. Пунктуація - ие набір правил використання розділових знаків, який має особливе значення в регулюванні законів орфографії. Іноді розділові знаки та пунктуація прирівнюються один до одного. Проте Заріфа Будагова справедливо розрізняє розділові знаки та пунктуачію, зазначаючи, що пунктуачія - ие система правил визначення їхньогомісия, тобтозастосування. Справді, колиправиланеутворюють систему, вони стають розділом науки, що називається пунктуацією. Також слід зазначити, щңо розділові знаки можна порахувати, і пунктуація - це загальне поняття, пов'язане зі розділовими знаками. Точніше було б сказати, щчо розділові знаки - ие об'єкт вивчення пунктуації. Загалом з історії лінгвістики стає зрозумілим, щзо з пунктуації було написано багато методологічних інструментів та наукових книг. Особливий інтерес у иіий галузі становлять погляди професора Заріфи Будагової. Питання пунктуаиії досліджено також у прачях М. Гусейнова, Г. Алієва, А. Казімова, В. Думаноглу. І. Аскер, Н. Палангов та інші лінгвістів. Книжку під назвою «Система пунктуачії в азербайджанській мові» видано нещодавно Академією наук Азербайджану. Мова постійно розвивається, інноващії тут не є винятком. У лінгвістів можуть бути різні підходи. Проте книга 3. Будагової «Знаки пунктуаиї̈ в азербайджанській мові» досі зберігає своє значення і завжди використовується як наукове першоджерело. Варто зазначити, щя серед розділових знаків кома вибрана як найбільш спірний і частий за зверненням до нього знак. Найпоширеніша помилка пунктуації в письмовій мові майже завжди пов 'язана з комами. У звіті також йдеться про розвиток цього знаку. Проведено порівняльний аналіз правил, наведених 3. Будаговою щцодо коми.

Ключові слова: пунктуачія, розділові знаки, кома, проблеми з пунктуачією, інтонація. 